\title{
LOW DOSES OF ATRAZINE CAUSE HORMESIS IN TRIBULUS TERRESTRIS
}

Mamoona Arooj ${ }^{1}$, Bilal Ahmad Khan*1, Muhammad Ather Nadeem ${ }^{1}$, Muhammad Mansoor Javaid ${ }^{1}$, Erum Rashid ${ }^{2}$, Muhammad Saleem Jilani ${ }^{3}$, Jamshahid Qamar ${ }^{1}$, Faryal Ali $^{4}$, Sadaf Javeria ${ }^{5}$, Muhammad Faisal ${ }^{4}$

\begin{abstract}
Growth stimulation due to ultra-low doses of different herbicides in several crop species has been observed both in controlled as well as in the field conditions; however available data of hermetic effects on weeds growth is very limited. This study investigates the promotive effect of low doses of atrazine on growth of Tribulus terrestris. Pot experiments were conducted at Agronomic Research Area, collage of Agriculture, University of Sargodha, during 2019. Six different concentrations of atrazine [0, 5, 10, 20, 40 and $80 \mathrm{~g}$ a.i. ha $\left.{ }^{-1}\right]$ were applied as post emergence herbicides at 3- 4 leaves stage of the weeds under two different water regimes (60\% and $100 \%$ water concentrations). Results revealed that increase in plant chlorophyll content, fresh weight, dry weight, root length and shoot length were observed after spraying of atrazine @ 5, 10 and $20 \mathrm{~g} \mathrm{a.i.} \mathrm{ha}{ }^{-1}$ at $100 \%$ water concentration. Doses of atrazine above $20 \mathrm{~g}$ a.i. ha ${ }^{-1}$ negatively affect the growth of Tribulus terrestris.
\end{abstract}

Keyword: Atrazine, dry weight, fresh weight, root length and shoot length

Citation: Arooj, M.; B.A. Khan; M. A. Nadeem; M. M. Javaid; E. Rashid; M. S. J Jlani; J. Qamar; F. Ali; S. Javaria; M. Faisal. 2021. Low Doses Of Atrazine Cause Hormesis In Tribulus Terrestris. Pak. J. Weed Sci. Res., 27 (3):351-358

${ }^{1}$ Department of Agronomy, College of Agriculture, University of Sargodha-40100, Pakistan.

2Department of Horticulture, College of Agriculture, University of Sargodha-40100, Pakistan.

${ }^{3}$ Dean faculty of Agriculture, Gomal University, Dera Ismail Khan, KPK, Pakistan.

${ }^{4}$ Department of Agronomy, University of Agriculture, Faisalabad, Pakistan.

5Director Food Science and nutrition, Gomal University, Dera Ismail Khan, KPK, Pakistan. 


\section{INTRODUCTION}

The stimulatory effect of sub-toxic doses of herbicides on crops has been studied as a possible means of increasing crop production. The general phenomenon of low doses of toxicants causing stimulatory responses is termed hormesis (Calabrese 2005). Hormetic responses of different toxicants have been reported in all groups of organisms, including higher plants (Calabrese 2005). To confirm the hormetic effects of herbicides, a study including 687 dose-response curves was conducted using 10 different herbicides and three plant species, and revealed that herbicides at low doses produced hormetic responses in $25-76 \%$ of the dose-response curves depending upon the plant species (Cedergreen et al. 2007). Herbicide hormesis can stimulate plant growth by up to $100 \%$, but, on average, $20-30 \%$ growth stimulation occurred at herbicide doses below $10 \%$ of the recommended field rate (Cedergreen et al. 2005). Consistent hormetic responses of different herbicides in wheat, rye, pea, soybean, barnyard grass, chickpea, maize, and barley have been reported by different researchers (Wagner et al. 2003; Duke et al. 2006; Velini et al. 2008; Cedergreen 2008a; Abbas et al. 2015).

Like other triazine herbicides, atrazine functions by binding to the plastoquinonebinding protein in photosystem II, which animal's lack. Plant death results from starvation and oxidative damage caused by breakdown in the electron transport process. Oxidative damage is accelerated at high light intensity. Research addressing to the effects of herbicide hormesis on weed growth and weed crop competition are currently absent. Most of the published research is about the hormetic responses of crops against herbicides (Davies et al., 2003; Duke et al., 2006; Cedergreen et al., 2007; Velini et al., 2010; Belz et al., 2011). However, for practical implementation of herbicide hormesis to improve crop growth and yield, the effects of these lower doses on weed growth should also be considered. Research on responses of weeds to hormetic doses of herbicides may also help us to understand the evolution of the mechanism of resistance, because for resistant biotypes of weeds the recommended field doses of some herbicides may also act as hormetic doses and can produce hormetic responses (Petersen et al., 2008). Therefore, this study was conducted to evaluate the promotive effect of different lower doses of atrazine on the growth of Tribulus terrestris $\mathrm{L}$.

\section{MATERIALS AND METHODS}

\section{Site and Soil}

The research work was conducted in pots having $7 \mathrm{Kg}$ soil to estimate the impact of ultra-low doses of Atrazine on Tribulus terrestris $\mathrm{L}$ under two water regimes at agronomy research area. College of Agriculture, University of Sargodha, Pakistan during summer season, 2019.

\section{Soil Analysis}

Before conducting of experiment and harvesting of crop soil analysis was done. By using soil auger soil sample was collected at the depth of 15 and $20 \mathrm{~cm}$ and additional information concerning to experimental area soil are displayed in table \# 1.

\section{Experimental design}

An experiment was carried out in pots to check the effect of ultra-low dose of atrazine on Tribulus terrestris $L$ under two irrigation regimes during summer season 2019. The experiment was laid out in pots under completely randomized design (CRD) with two factors; each factor replicated four times. Each pot having 7 $\mathrm{kg}$ of soil. The experiment was comprised of following treatments.

\section{Treatments}

\section{Factor A: water regimes}

Normal irrigation (100 \% F. C)

Drought (60 \% F.C)

\section{Factor B: Weedicide doses}

$\mathbf{T}_{\mathbf{1}}=0.0$ dose a.e. ha 
$\mathbf{T}_{\mathbf{2}}=5.0 \mathrm{~g}$ a.e. $\mathrm{ha}^{-1}$

$\mathbf{T}_{\mathbf{3}}=10.0 \mathrm{~g}$ a.e. $\mathrm{ha}^{-1}$

$\mathbf{T}_{\mathbf{4}}=20.0 \mathrm{~g}$ a.e. $\mathrm{ha}^{-1}$
$\mathbf{T}_{5}=40.0 \mathrm{~g}$ a.e. $\mathrm{ha}^{-1}$

$\mathbf{T}_{6}=80.0 \quad \mathrm{~g}$ a.e. $\mathrm{ha}^{-1}$

Table \# 1 Physio-chemical analysis of soil from experimental area

\begin{tabular}{ll}
\hline Characteristics & Soil sample \\
\hline Soil Ph. & 7.8 \\
E.C $\left(\mathrm{mS} \mathrm{cm}^{-1}\right)$ & 2.18 \\
Organic matter $(\%)$ & 0.97 \\
$\mathrm{~N}(\%)$ & 0.41 \\
Available P (ppm) & 8.4 \\
Available K (ppm) & 180 \\
Saturation $(\%)$ & 40 \\
Texture & Loam \\
\hline
\end{tabular}

\section{Procedure for maintaining water limited condition}

Water limiting condition was maintained by calculating field capacity. Calculations were made by filling $7 \mathrm{~kg}$ air dry soil in each uniform size pot. Hole below the pot was blocked by placing the paper towel at the base prior to filling with soil. Sample of air dry soil was kept in oven at $105^{\circ} \mathrm{C}$ for oven drying till constant weight. Soil in pot should be fully saturated with water and kept overnight till drainage of excess water from pot. Sample of soil will be weighed and kept in oven to get dry weight of soil. Weight of water in pot was determined by subtracting oven dry weight of soil from total weight of wet soil after drainage of excess water. Water which was present at the time of filling of soil in pot was added in it.

Quantity of water needed to maintain $100 \%$ F.C was determined by using following formula:

Water required to maintain $100 \%$ F.C $=$ (weight of water/ weight) $\times 100$

Quantity of water need to maintain $60 \%$ F.C was determined as follows
Water required to maintain $60 \% \mathrm{~F} . \mathrm{C}=$ $(60 / 100) \times$ water required to maintained $100 \%$ F.C.

Target weight of each pot for each field capacity level will be maintained throughout the conduct of experiment.

\section{Crop husbandry:}

Tribulus terrestris L was sown on 06-092019. Before sowing the soil was ploughed manually by hand tools to loose the soil and prepared a good fine seed bed. Ten seeds/pot were planted manually to obtain maximum germination. Thinning was done ten days after germination of seeds leaving four plants/pot. Spray the herbicides on crop at 3-4 leaf stage after germination of crop. The plants were harvested from each pot $21^{\text {st }}$ days after spray.

\section{Ultra-low dose of weedicides}

Ultra-low dose of all herbicides were applied with a backpack atomizer equipped with a flat- fan (tee jet 8002 Nozzle, spraying system company, wheaton, 1L) at four weeks after the emergence of Tribulus terrestris $\mathrm{L}$. Calibration was done to deliver $250 \mathrm{~L}$ per 
hectare at walking speed of $3.3 \mathrm{~km}$ per hectare.

\section{Procedure for recording data}

The data were recorded by using following standard procedure from each treatment.

\section{Fresh weight $(g)$}

Plant fresh weight of plants was examined at $21^{\text {st }}$ day after spray from each treatment in each replication. An electric balance was used to measure fresh weight of plant.

\section{Dry weight (g)}

For dry weight four plants that were already uprooted for fresh weight placed at $60{ }^{\circ} \mathrm{C}$ for period of 48 hours in an oven. The dry weight of these plants was measured with the help of an electric balance and then take average.

Chlorophyll contents (mg)
Chlorophyll content of four plant from each pot was measured $21^{\text {st }}$ days after spray by using photo meter then take average.

\section{Shoot length $(\mathrm{cm})$}

Shoot length of plant was observed 21 days after spray from ground level to shoot tip with the help of meter rod and then take average.

\section{Root length (g)}

Plants root length was recorded 21 days after spray with meter from start of root to root tip then take average.

\section{Statistical analysis}

The data recorded was analyzed statistically by using the MSTAT $C$ for analysis of variance and significance of treatment mean was tested using Tukey's honestly significance difference (HSD) test at $5 \%$ probability level (steel et al., 1997).

\section{Results}

Table 2.1: Effect of ultra-low dose of atrazine on chlorophyll content\% ( $\mathrm{g}$ ) of Tribulus terrestris $L$ under two irrigation regimes

\begin{tabular}{|llll|}
\hline $\begin{array}{l}\text { Herbicide dose (g a.e. } \\
\text { ha }^{-\mathbf{1}} \text { ) }\end{array}$ & \multicolumn{3}{c}{ Plant chlorophyll content (\%) } \\
\cline { 2 - 4 } & Normal irrigation & Drought & Mean \\
\hline 0.0 (Control) & 33.26 & 32.73 & $\mathbf{3 2 . 9 9 a b}$ \\
5.0 & 32.15 & 32.74 & $\mathbf{3 2 . 4 5 a b}$ \\
10 & 34.58 & 33.82 & $\mathbf{3 4 . 2 0 a}$ \\
20 & 34.13 & 34.22 & $\mathbf{3 4 . 1 7 a}$ \\
40 & 29.63 & 28.88 & $\mathbf{2 9 . 2 5 b}$ \\
80 & 16.16 & 14.11 & $\mathbf{1 5 . 1 4 c}$ \\
\hline Mean & $\mathbf{2 9 . 9 8}$ & $\mathbf{2 9 . 4 2}$ & \\
\hline
\end{tabular}

LSD: Herbicide $=4$, Irrigation regimes $=6.93$, Herbicide $\times$ Irrigation regimes $=2.83$

Mean sharing the same letter did not different with each other at $5 \%$ probability level 
Table 2.2: Effect of ultra-low dose of atrazine on fresh weight (g) of Tribulus terrestris $L$ under two irrigation regimes

Herbicide dose (g a.e. $\mathbf{h a}^{-1}$ )

Plant fresh weight (g)
Normal irrigation Drought

\begin{tabular}{|llll|}
\hline 0.0 (Control) & $8.59 a$ & $6.69 c$ & $\mathbf{7 . 6 4 a}$ \\
5.0 & $8.68 a$ & $6.87 c$ & $\mathbf{7 . 7 7 a}$ \\
10 & $8.84 a$ & $7.08 c$ & $\mathbf{7 . 9 6 a}$ \\
20 & $8.57 a$ & $6.93 c$ & $\mathbf{7 . 7 5 a}$ \\
40 & $7.78 b$ & $5.36 e$ & $\mathbf{6 . 5 7 b}$ \\
80 & $5.93 d$ & $5.48 d e$ & $\mathbf{5 . 7 0 c}$ \\
\hline Mean & $\mathbf{8 . 0 6 a}$ & $\mathbf{6 . 4 0 b}$ &
\end{tabular}

LSD: Herbicide $=0.72$, Irrigation regimes $=1.26$, Herbicide $\times$ Irrigation regimes $=0.51$ Mean sharing the same letter did not different with each other at $5 \%$ probability level

Table 2.3: Effect of ultra-low dose of atrazine on dry weight (g) of Tribulus terrestris $L$ under two irrigation regimes

\begin{tabular}{|c|c|c|c|}
\hline \multirow{2}{*}{$\begin{array}{l}\text { Herbicide dose (g a.e. } \\
\text { ha }^{-1} \text { ) }\end{array}$} & \multicolumn{3}{|c|}{ Plant dry weight (g) } \\
\hline & Normal irrigation & Drought & Mean \\
\hline 0.0 (Control) & 1.40 & 1.10 & $1.25 a$ \\
\hline 5.0 & 1.45 & 1.14 & $1.29 a$ \\
\hline 10 & 1.47 & 1.18 & $1.33 a$ \\
\hline 20 & 1.43 & 1.14 & $1.28 a$ \\
\hline 40 & 1.30 & 0.89 & $1.09 b$ \\
\hline 80 & 1.09 & 0.83 & $0.96 c$ \\
\hline Mean & $1.36 a$ & $1.05 b$ & \\
\hline $\begin{array}{l}\text { LSD: Herbicide }=0.12, \text { I } \\
=0.09\end{array}$ & rrigation regimes $=0$ &, $\mathrm{He}$ & gation regimes \\
\hline \multicolumn{4}{|c|}{ Mean sharing the same letter did not different with each other at $5 \%$ probability level } \\
\hline \multicolumn{4}{|c|}{$\begin{array}{l}\text { Table 2.4: Effect of ultra-low dose of atrazine on root length }(\mathrm{cm}) \text { of Tribulus } \\
\text { terrestris } L \text { under two irrigation regimes }\end{array}$} \\
\hline \multirow{2}{*}{$\begin{array}{l}\text { Herbicide dose (g a.e. } \\
\text { ha }^{-1} \text { ) }\end{array}$} & \multicolumn{3}{|c|}{ Root length $(\mathrm{cm})$} \\
\hline & Normal irrigation & Drought & Mean \\
\hline 0.0 (Control) & 9.85 & 9.60 & $9.73 a$ \\
\hline 5.0 & 9.80 & 9.44 & $9.62 \mathrm{a}$ \\
\hline 10 & 10.00 & 9.99 & 9.99a \\
\hline 20 & 9.91 & 9.55 & $9.73 a$ \\
\hline 40 & 9.24 & 8.73 & $8.98 a$ \\
\hline 80 & 6.88 & 7.80 & 7.34b \\
\hline
\end{tabular}




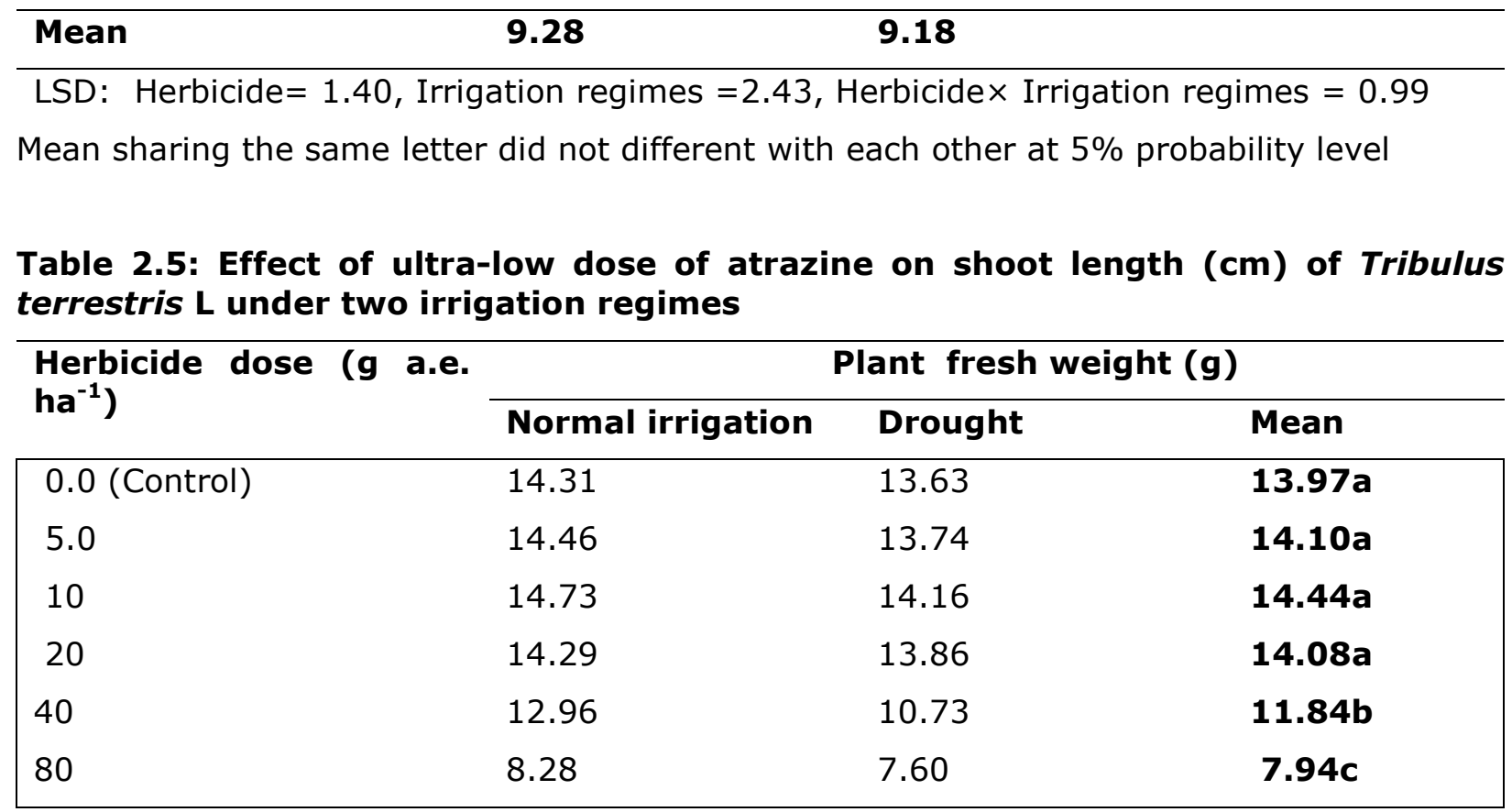

\begin{tabular}{lll} 
Mean & $\mathbf{1 3 . 1 7}$ & $\mathbf{1 2 . 2 9}$ \\
\hline LSD: Herbicide $=1.36 \quad$, Irrigation regimes $=2.36 \quad$, Herbicide $\times$ Irrigation regimes \\
$=0.96$
\end{tabular}

Mean sharing the same letter did not different with each other at 5\% probability level

\section{Results:}

\section{Chlorophyll content (\%):}

Chlorophyll is a natural green pigment found in photosynthetic organisms such as plants and algaes. Chlorophyll is vital for photosynthesis, allowing plants to absorb energy from light. Quantity of chlorophyll per unit area is an indicator of photosynthetic capacity of a plant. Higher photosynthetic capacity means higher production rate. Data pertaining to the effect of ultra-low dose of atrazine on chlorophyll content (\%) of leaves under two irrigation regimes recorded at 21 days after atrazine application is presented in table 2.1 (a). Data showed that ultra-low dose of atrazine at the rate of $10 \mathrm{~g}$ a.e ha${ }^{1}$ produced significantly higher chlorophyll content than the treatments where the atrazine was applied at higher rates i.e., 40 and $80 \mathrm{~g}$ a.e. $\mathrm{ha}^{-1}$. However, it is statistically at par with the treatments where the atrazine was applied at the rate of 0,5 and $20 \mathrm{~g}$ a.e ha ${ }^{-1}$. The lowest chlorophyll content was observed where the atrazine was applied at the rate of 80 g a.e ha-1.

In case of water regimes, normal irrigation treatment showed more chlorophyll content than drought treatment but these are non-significantly different with each other. The results showed that interaction between herbicidal treatment and irrigation regimes were non-significant.

\section{Fresh weight:}

Fresh weight of a crop is vegetative growth and yield determining traits of crops. Studies showed that plant biomass was due to more vegetative growth, number of branches, and number of flowers per plant which leads to higher crop yield. Data presented by table (2.2) showed that fresh weight was significantly affected by different levels of atrazine. Atrazine at $10 \mathrm{~g}$ a.e. gave highest fresh weight followed by 5,20 and $0 \mathrm{~g}$ a.e. respectively. The minimum fresh weight was obtained in the treatment where the atrazine was applied at $80 \mathrm{~g}$ a.e. 
The results revealed that normal irrigation gave significantly higher fresh weight $(8.06 \mathrm{~g})$ than drought condition $(6.40 \mathrm{~g})$. The interaction between different levels of treatments and irrigation regimes were found to be significant. However, the highest fresh weight was obtained where the atratize was applied at $10 \mathrm{~g}$ a.e. under normal irrigation condition.

\section{Dry weight (g):}

Table (2.3) demonstrates that all treatments of atrazine and irrigation regimes had a vital effect on the dry weight $(\mathrm{g})$. Results showed that ultra-low dose of atrazine (10 g a.e.) showed maximum dry weight followed by 5 and 20. The control treatment was also statistically at par with the treatments of atrazine at 5, 10 and $20 \mathrm{~g}$ a.e.

Again the normal irrigation showed statistically higher dry weight than drought. However the results remain nonsignificant for interactions of different atrazine levels and irrigation regimes.

\section{Root length $(\mathrm{cm})$ :}

Root length was also significantly affected by different levels of atrazine. However, the atrazine at the rate of $10 \mathrm{~g}$ a.e. showed maximum root length (9.99) as compared to other levels of atrazine. The minimum root length $(7.34 \mathrm{~cm})$ was observed where the atrazine was applied at its highest level i.e., $80 \mathrm{~g}$ a.e. Table (2.4) showed that normal irrigation showed higher root length than the drought conditions but the difference was non-significant. The interaction between herbicidal treatments and irrigation regimes was also non-significant.

\section{Shoot length $(\mathbf{c m})$ :}

Table (2.5) showed that atrazine at its lower levels i.e., 0,5,10 and $20 \mathrm{~g}$ a.e. produced significantly long shoots than higher levels of atrazine (40 and $80 \mathrm{~g}$ a.e.). Normal irrigation also produced lengthy shoots $(13.17 \mathrm{~cm})$ than drought conditions $(12.29 \mathrm{~cm})$ but the difference was non-significant. Data showed that interaction between different levels of atrazine and irrigation regimes was remain non-significant.

\section{Discussion:}

Atrazine at the rate of $10 \mathrm{~g}$ a.e. produced statistically higher chlorophyll content, fresh weight, dry weight, root length and shoot length than atrazine applied at 40 and $80 \mathrm{~g}$ a.e. Treatments 0,5 and $20 \mathrm{~g}$ a.e. were statistically at par with $10 \mathrm{~g}$ a.e. applied treatment. Normal irrigation produced statistically more chlorophyll content, fresh weight, dry weight, root length and shoot length than drought conditions.

There are very few researches available in the literature with results of hormesis caused by atrazine or some other herbicide with a hormetic effect on Tribulus terrestris L. Tavares et al. (2017) applied sub-doses of $2,4-\mathrm{D}$ on pequi seedlings and showed hormetic effects based on the leaf area, specific leaf area, and leaf area ratio with doses of $3.3 \mathrm{~g}$ ha$1,1.65 \mathrm{~g}$ ha-1, and $3.35 \mathrm{~g}$ ha-1, respectively. In a study carried out by Silva (2014), the hormetic effect was shown on soybean crops, but with the application of sub- doses of glyphosate. In this case, the application of $3.6 \mathrm{~g}$ ha- 1 of glyphosate followed by a fresh application of $3.2 \mathrm{~g}$ ha-1 after 14 days induced the maximum growth of the plant shoot, probably in response to the increase in the production of amino acids. Also, Silva (2014) verified that, for total dry mass, a dose of $7.2 \mathrm{~g}$ ha-1 of glyphosate, applied 14 days after an application of an initial dose of $18.2 \mathrm{~g}$ ha-1, provided a more evident hormetic effect. 


\section{References:}

Abbas T., M. A. Nadeem, A. Tanveer, A. Zohaib and T. Rasool. 2015. Glyphosate hormesis increases growth and yield of chick pea (Cicer arietinum L.). Pak. J. Weed Sci. Res. 21:533-542.

Belz R.G., N. Cedergreen and S. O. Duke. 2011. Herbicide hormesis- can it be useful in crop production? Weed Res. 51:321-32.

Calabrese E. J. 2005. Paradigm lost, paradigm found: The re-emergence of hormesis as a fundamental dose response model in the toxicological sciences. Environ Pollution. 138:378-411.

Cedergreen N., C. S. Ritz and J. C. Treibig. 2005. Improved empirical models describing hormesis.

Environ. Toxicol. Chem. 24:31663172.

Cedergreen N., J. C. Streibig, P. Kudsk, S. K. Mathiassen and S. O. Duke. 2007. The occurrence of hormesis in plants and algae. Dose-Response. 5:150162.

Cedergreen N. 2008a. Is the growth stimulation by low doses of glyphosate sustained over time? Environ. Pollut. 156:1099-1104.

Cedergreen N. et al. 2007. The occurrence of hormesis in plants and algae. DoseResponse. 5:150-

Davies J. J. L. Honegger, F. G. Tencalla, G. Meregalli, P. Brain, J. R. Newman, H. F.Pitchford. 2003. Herbicide risk assessment for nontarget aquatic plants: sulfosulfuron a case study. Pest Manag. Sci. 59:231-7.

Duke S. O., N. Cedergreen, R. Belz and E. Velini. 2006. Hormesis: is it an important factor in herbicide use and allelopathy? Outlooks Pest Manag. 17:29-33.

Petersen J., J. M. Neser, and M. DresbachRunkel. 2008. Resistant factors of target-site and metabolic resistant blackgrass (Alopecurus myosuroides Huds.) biotypes against different ACC-ase-inhibitors. J. Plant Dis. Protect. 11:25-30.

Silva F.M.L. Hormesis de herbicidas em soja. [tese]. Botucatu: Universidade Estadual Paulista "Julia de Mesquita Filho"; 2014.

Steel R.G.D., J.H. Torrie and D. A. Dickey. Principles and procedures of statistics: a biometrical approach. 3rd. ed. New York: McGraw Hill Book, 1997. Pp.172-7.

Tavares C. J., L.S. Pereira, A. C. F. Araújo, D. A. M. Martins and A. Jakelaitis.2017. Crescimento inicial de plantas de pequi após aplicação de 2, 4-D. Pesq Flor Bras.37 (89):81-7.

Velini E.D., E. Alves, M.C. Godoy, D.K. Meschede, R.T. Souza and S.O. Duke. 2008. Glyphosate at low doses can stimulate plant growth. Pest Manag. Sci. 64:489-496.

Velini E.D., M. Trindade, L. Barberis, and S. Duke. 2010. Growth regulation and other secondary effects of herbicides. Weed Sci. 58:351-4.

Wagner R., M. Kogan and A.M. Parada. 2003. Phytotoxic activity of root absorbed glyphosate in corn seedlings (Zea mays L.). Weed Biol. Manage. 3:228-232. 